\title{
Marcos Tomanik Mercadante (1960-2011)
}

\author{
Walmor J. Piccinini
}

A capa da revista Fapesp (http://revistapesquisa.fapesp.br/) de junho passado aborda o autismo como assunto. A reportagem é de Ricardo Zorzeto e seu título é O Cérebro no Autismo. Mercadante é citado várias vezes como colaborador e especialista no assunto. Sua dedicação na pesquisa e no atendimento de autistas está nela refletido e foi uma das razões da criação da ONG Autismo \& Realidade. Em junho, ele aparece colaborando com a reportagem e, em 2 de julho, ocorre sua morte após um ano de sofrimento com uma doença terminal. O Jornal Brasileiro de Psiquiatria presta sua homenagem a esse colaborador, amigo, professor, pesquisador, ativo participante do Departamento de Psiquiatria da Infância e Adolescência da Associação Brasileira de Psiquiatria.

Mercadante era alto, forte e afetuoso no trato com todos. Era um gigante gentil para com todos que com ele conviviam. Pai de quatro filhos, Julia (25), advogada; Mariana (22), estudante de medicina; João (13), estudante, e o mais jovem, Diogo, filho do seu segundo casamento. De uma colega recebi a seguinte mensagem: "Foi muito triste, ele faleceu depois de um ano de luta contra um câncer de pâncreas. É de admirar a coragem e a força com que lutou sempre otimista, acreditando que descobririam novos tratamentos, fiel à crença na ciência e a ela se dedicando. Mesmo doente, preparava aulas, pensava em fazer a livre-docência. Encarou a adversidade com otimismo e planejando o futuro, cuidando de deixar um legado intelectual e emocional a seus filhos. Sua trajetória como estudante médico e professor foi carregada de conquistas. Entrou para o Curso de Medicina da USP aos 18 anos, formou-se com 24. Fez mestrado na PUCSP com o trabalho "Negociando o Diagnóstico Clínico", concluído em 1993. Em 1999 concluiu doutorado na psiquiatria da USP com o trabalho "Transtorno Obsessivo-Compulsivo, Síndrome de Tourette e outros transtornos psiquiátricos em pacientes com febre reumática com e sem Coreia de Sydenham".

Sua trajetória como professor começa na Universidade Paulista (UNIP) nos anos de 19871989, onde lecionava Psiquiatria da Infância. Na Santa Casa de São Paulo, foi chefe do setor de Psiquiatria Infantil (1989-1995). Na Mackenzie (Universidade Presbiteriana Mackenzie), foi professor adjunto no período de 2002 a 2007. Em 2006, aprovado por concurso, tornou-se professor adjunto da Universidade Federal de São Paulo (Unifesp).

Desde 1995 venho trabalhando no Índice Bibliográfico Brasileiro de Psiquiatria (www.biblioserver.com/walpicci). Este trabalho que se aproxima das 19 mil referências bibliográficas e que procura valorizar quem faz pesquisa e publica na área da psiquiatria me proporcionou a oportunidade de conhecer e travar amizade com muitos pesquisadores que passaram a ser vistos por mim como se fossem parte de uma grande família. Nem a todos conheço pessoalmente, mas posso desfrutar da amizade de muitos. No índice registramos 114 publicações de Marcos T. Mercadante, são artigos, capítulos de livros e livros por ele organizados. Orientou 12 dissertações de mestrado e uma tese de doutorado. Como editor da Revista Brasileira de Psiquiatria, sua colaboração foi também inestimável. 